\title{
Time- and concentration-dependent cytotoxicity of antibiotics used in endodontic therapy
}

\author{
Marina Beloti FERREIRA ${ }^{1}$, Suely MYIAGI'2, Carlos Goes NOGALES ${ }^{1}$, Marcia Sampaio CAMPOS $^{3}$, \\ José Luiz LAGE-MARQUES ${ }^{4}$ \\ 1- DDS, MsC, Department of Restorative Dentistry, Discipline of Endodontics, Dental School of University of São Paulo, São Paulo, Brazil. \\ 2- DDS, PhD, Department of Restorative Dentistry, Discipline Of Endodontics, Dental School of University of São Paulo, São Paulo, Brazil. \\ 4- DDS, PhD, Department of Pathology, Dental School of University of São Paulo, São Paulo, Brazil. \\ 5- Associate Professor of Restorative and Endodontics, Department of the Dental School of University of São Paulo.
}

Corresponding address: Marina Beloti Ferreira - Rua Heitor Penteado, 1832 - ap 504 BI B - Sumarezinho - São Paulo-SP - $05438-300$ - Tel: 55 (11) 8451 1557 - e-mail: marinabeloti@uol.com.br

Received: December 8, 2008 - Modification: July 20, 2009 - Accepted: April 13, 2010

\section{ABSTRACT}

O bjective: New drugs have to be assessed in endodontic therapy due to the presence of microorganisms resistant to therapeutic procedures. Thus, this study evaluated the time- and concentration-dependent cytotoxicity of different antibiotics used in endodontic therapy. Material and Methods: Human gingival fibroblasts were treated and divided into the following experimental groups: Group I - control; Group II - ciprofloxacin hydrochloride; Group III - clyndamicin hydrochloride; and Group IV - metronidazole. Each drug was used at concentrations of 5, 50, 150, and $300 \mathrm{mg} / \mathrm{L}$ for 24, 48, 72, and $96 \mathrm{~h}$. Cytotoxicity was evaluated by the MTT assay [3-(4,5-dimethylthiazol-2-yl)-2,5-diphenyltetrazolium bromide] and spectrophotometric reading of ELISA plates. The results were analyzed by BioEstat 4.0 software using Kruskal-Wallis and Dunn's tests at a significance level of $5 \%$. Cell viability was assessed for the different concentrations and times. RESULTS: All drugs presented dose-dependent cytotoxicity. Concentrations of 5 and $50 \mathrm{mg} / \mathrm{L}$ produced viable fibroblasts at all experimental times in all groups. Conclusions: Cell viability at $24 \mathrm{~h}$ was greater than in the other experimental times. Comparison between the same concentrations of antibiotics at different times showed that metronidazole presented the highest cell viability at 72 and $96 \mathrm{~h}$ compared to the other antibiotics, whereas clyndamicin hydrochloride showed higher cell viability at $72 \mathrm{~h}$ than ciprofloxacin hydrochloride.

Key words: Cytotoxicity. Ciprofloxacin. Clyndamicin. Metronidazole.

\section{INTRODUCTION}

Successful endodontic treatment involves the removal of the etiological agent, which most of the times is a microorganism. Although chemomechanical preparation aims at eliminating microorganisms from the root canal system, this procedure may not be sufficient to eliminate the focus of infection because some pathogens remain viable in the main canal and in dentinal tubules, needing dentin desmineralization and intracanal dressing.

In other clinical situations, not even the association of chemomechanical preparation and drug therapy is effective in eliminating endodontic infections because of the presence of microorganisms resistant to drugs and chemical agents, and the formation of biofilms in the periapical region. These situations require alternative interventions, such as the combination of antibiotics to achieve adequate concentrations in the dentinal tubules, so that they can act in areas that are not reached by the endodontic instruments and irrigating solutions, and kill resistant and facultative anaerobic microorganisms.

Among the drugs commonly used for endodontic infections, ciprofloxacin is indicated due to its efficient action against oral anaerobes, grampositive aerobic microorganisms (Staphylococcus aureus, S. epidermidis, Sptreptococcus spp) and gram-negative enterobacteria (Escherichia coli, Enterobacter spp and Pseudomonas), which show MIC $_{90}$ between 0.015 and $2 \mu \mathrm{g} / \mathrm{mL}$. All streptococcal species are sensitive to concentrations between 1.0 and $8.0 \mu \mathrm{g} / \mathrm{mL} ;$ S. aureus and S. epidermidis are 
sensitive to concentrations between 0.25 and 1.0 $\mu \mathrm{g} / \mathrm{mL}^{10}$. Metronidazole has a unique spectrum of activity, covering strict anaerobic Gram-positive and Gram-negative bacteria, and protozoa ${ }^{3}$. Its bactericidal action involves breaking bacterial DNA and inhibiting nucleic acid synthesis, and affects almost all gram-negative anaerobic bacilli5. Clyndamicin acts on resistant root canal microbiota, gram-positive aerobic bacilli, such as S. aureus, $S$. epidermidis and Pneumococci, as well as on grampositive and gram-negative bacteria ${ }^{10}$.

In addition to the antimicrobial action, the cytotoxicity of antibiotics used in endodontic therapy should be determined, as it may provide a scientific basis for professionals making a decision on the most biocompatible drugs to be used. The aim of this study was to assess the cytotoxicity of ciprofloxacin hydrochloride, clyndamicin hydrochloride and metronidazole on human gingival fibroblast cultures.

\section{MATERIAL AND METHOD}

The human gingival fibroblasts (FMM1) used in this study were donated by the Basic Research Laboratory of the Dental School of the University of São Paulo, Brazil. The present study was approved by the Research Ethics Committee of the University of São Paulo (Protocol number 02/05).

Cells were thawed in water at $37^{\circ} \mathrm{C}$ for $30 \mathrm{~s}$ and transferred to a $65 \mathrm{~cm}^{2}$ cell culture bottle containing $15 \mathrm{~mL}$ of culture broth. Cells were kept at $37^{\circ} \mathrm{C}$ in moist environment with $95 \%$ air and $5 \% \mathrm{CO}_{2}$. Cell growth was assessed every $24 \mathrm{~h}$ with an inverted phase microscope, until cells were confluent (Figure 1). Broth was changed every other day in order to maintain cell viability. Cells were subcultured to the sixth passage, when a standard number of cells were obtained for the assay.

In order to determine the number of cells in the original flasks, cells were submitted to trypsin treatment and transferred to a test tube that was centrifuged at $300 \mathrm{rmp}$ for $5 \mathrm{~min}$ at room temperature. Cells were counted in a Neubauer chamber $^{5}$, and Dulbecco's Modified Eagle Medium (DMEM) was added to the original bottles in a sufficient amount to produce $10^{3}$ cells in each 200 $\mu \mathrm{L}$-well of the culture plate ${ }^{4}$.

One 96-well plate was used for each of the following experimental times: 24, 48, 72, and 96 h. The wells were filled with $200 \mu \mathrm{L}$ culture broth with $10^{3}$ cells/well, and the plates were kept in an incubator with $5 \% \mathrm{CO}_{2}$ atmosphere at $37^{\circ} \mathrm{C}$ for 24 $\mathrm{h}$ for cell adherence.

The concentration of the drugs used in this assay followed the protocol proposed by Gürbay, et al. ${ }^{7}$ (2007). The following groups were formed: Group I: Control (cells in culture broth); Group II: ciprofloxacin hydrochloride (300, 150, 50 and 5 $\mathrm{mg} / \mathrm{L}$ ); Group III: Clyndamicin hydrochloride (300, 150,50 and $5 \mathrm{mg} / \mathrm{L}$ ); Group IV: Metronidazole gel $10 \%(300,150,50$ and $5 \mathrm{mg} / \mathrm{L})$. The drugs were prepared at the Basic Research Laboratory of the Dental School of the University of São Paulo, Brazil. Each drug was diluted in distilled water and added to the culture broth (DMEM). Experimental times of $24,48,72$ and $96 \mathrm{~h}$ were used in all groups.

After $24 \mathrm{~h}$ of plating the cultures, broth was carefully aspirated in order not to break the monolayer. After that, $200 \mu \mathrm{L}$ of each concentration of the tested drugs were added to the different plates. The control group was treated with $200 \mu \mathrm{L}$ of culture broth. After $48 \mathrm{~h}$, the culture medium of the plates incubated for 72 and $96 \mathrm{~h}$ was changed: the control group received fresh broth and the other plates, new dilutions of the antibiotics. After confirming the results, the assay was repeated other two times, totalizing three repetitions.

The mitochondrial activity of the fibroblasts was assessed by the MTT assay [3-(4,5-dimethylthiazol2-yl)-2,5-diphenyltetrazolium bromide] at the end of each experimental period. The contents of each well were gently stirred with a multichannel pipettor and submitted to absorbance reading at $560 \mathrm{~nm}$ in an ELISA spectrophotometer. Absorbance results were analyzed, converted in cell viability percentages and compared in the statistical analysis. The level of significance was set at $5 \%$.

\section{RESULTS}

Data on mitochondrial activity obtained from the optical density of cell culture plates of the experimental groups were transformed in percentages in relation to the control group, considered to be $100 \%$. These values are shown in Table 1 and illustrated in Figures 2 to 5 , and are related to each group of standard fibroblast culture treated by different antibiotic concentrations for different experimental times.

Table 1 shows that at $24 \mathrm{~h}, 5$ and $50 \mathrm{mg} / \mathrm{L}$ of ciprofloxacin produced at least $60 \%$ cell viability, decreasing in the next experimental period and increasing until $96 \mathrm{~h}$. Concentrations of 150 and $300 \mathrm{mg} / \mathrm{L}$ produced the smallest number of viable cells at all experimental times. The Kruskal-Wallis test was used with the Dunn's test because of the non-normal distribution of the number of viable cells. Significance level set at 5\% for the different interactions between each antimicrobial agent and their different concentrations and experimental times.

Concentrations of 5 and $50 \mathrm{mg} / \mathrm{L}$ of clyndamicin produced about $60 \%$ viable cells at 24 and $48 \mathrm{~h}$, and over $70 \%$ at the last two experimental times. Concentrations of 150 and $300 \mathrm{mg} / \mathrm{L}$ led to less than 
50 and $20 \%$ of viable cells at 24 and $48 \mathrm{~h}$ and a decrease in the number of cells after $96 \mathrm{~h}$.

Figure 2 shows normal fibroblasts in the control group. At $24 \mathrm{~h}$, cells were fusiform with central nucleuses and typical cytoplasmic extensions, which have an important role in cell contact. At $48 \mathrm{~h}$, there were more viable cells, occupying about $70 \%$ of the wells, representing the subconfluence state. At 96 $\mathrm{h}$, cells were confluent and overlapping.

Figure 3 shows the ciprofloxacin-treated group. Representative images obtained for the concentrations of 5 and $50 \mathrm{mg} / \mathrm{L}$ showed that fibroblasts were fusiform with central nucleuses and typical cytoplasmic extensions. For the concentration of $150 \mathrm{mg} / \mathrm{L}$, the smallest number of cells was observed with the greatest spacing between them. For the concentration of $300 \mathrm{mg} / \mathrm{L}$, there were particles among the few existing cells suggesting the drug precipitated (Figure 3A).

Figure 4 shows the clyndamicin-treated group. Fibroblasts treated with 5 and $50 \mathrm{mg} / \mathrm{L}$ were fusiform with central nucleuses and typical cytoplasmic extensions. For the concentration of $150 \mathrm{mg} / \mathrm{L}$, fewer, unattached, round cells with

Table 1- Mean cell viability (\%) of fibroblasts according to the tested antibiotics, concentrations and experimental times

\begin{tabular}{|c|c|c|c|c|c|c|c|c|c|c|c|c|}
\hline & & $24 \mathrm{~h}$ & & & $48 h$ & & & $72 \mathrm{~h}$ & & & $96 h$ & \\
\hline & $\mathrm{CP}$ & CL & M & $\mathrm{CP}$ & CL & M & CP & CL & M & CP & CL & M \\
\hline $5 \mathrm{mg} / \mathrm{L}$ & 78.61 & 70.06 & 71.01 & 55.84 & 66.16 & 68.15 & 83.80 & 77.32 & 71.34 & 69.88 & 81.68 & 73.95 \\
\hline 50 mg/L & 63.31 & 65.37 & 68.0 & 35.32 & 58.96 & 61.33 & 51.29 & 72.09 & 62.97 & 53.07 & 71.31 & 67.68 \\
\hline $150 \mathrm{mg} / \mathrm{L}$ & 37.56 & 45.35 & 62.75 & 26.87 & 36.16 & 56.97 & 33.39 & 42.74 & 56.33 & 29.31 & 30.50 & 62.90 \\
\hline $300 \mathrm{mg} / \mathrm{L}$ & 27.22 & 15.71 & 53.38 & 9.36 & 5.86 & 55.05 & 17.10 & 13.83 & 53.25 & 10.79 & 0.83 & 57.66 \\
\hline
\end{tabular}

CP: Ciprofloxacin; CL: clyndamicin; M: metronidazole

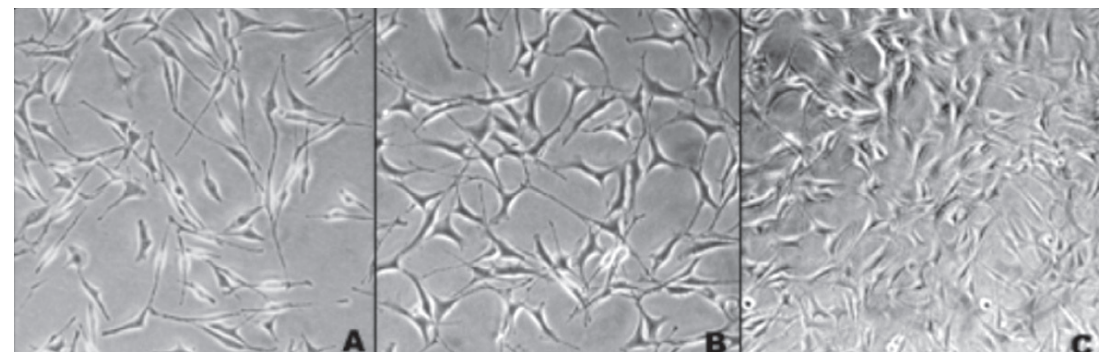

Figure 1- Monitoring fibroblast growth. (A) and (B) fibroblast increasing; (C) cells in subconfluence

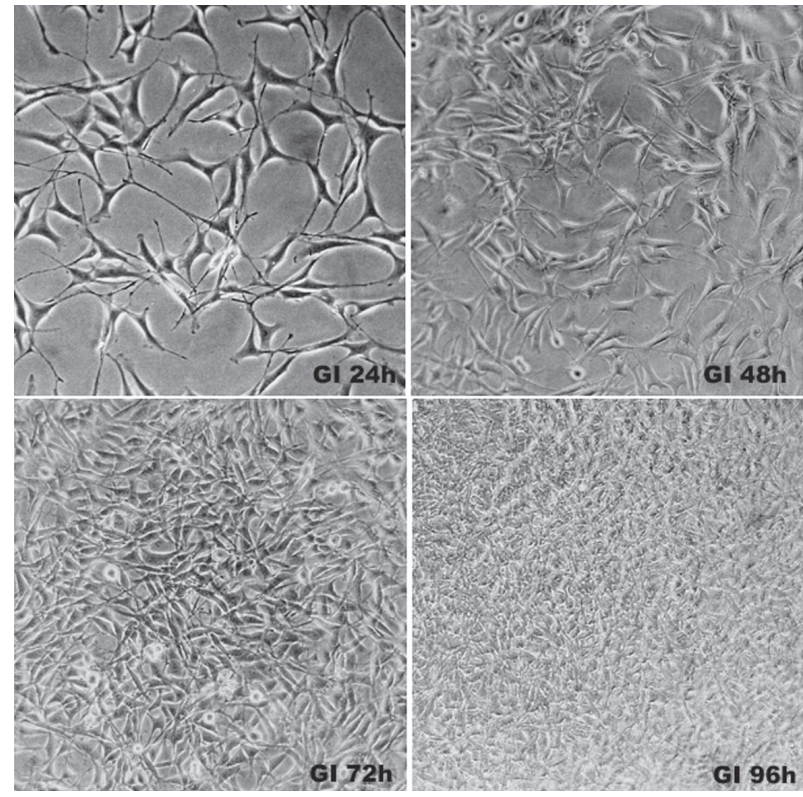

Figure 2- Photomicrographs of Group I (Control)

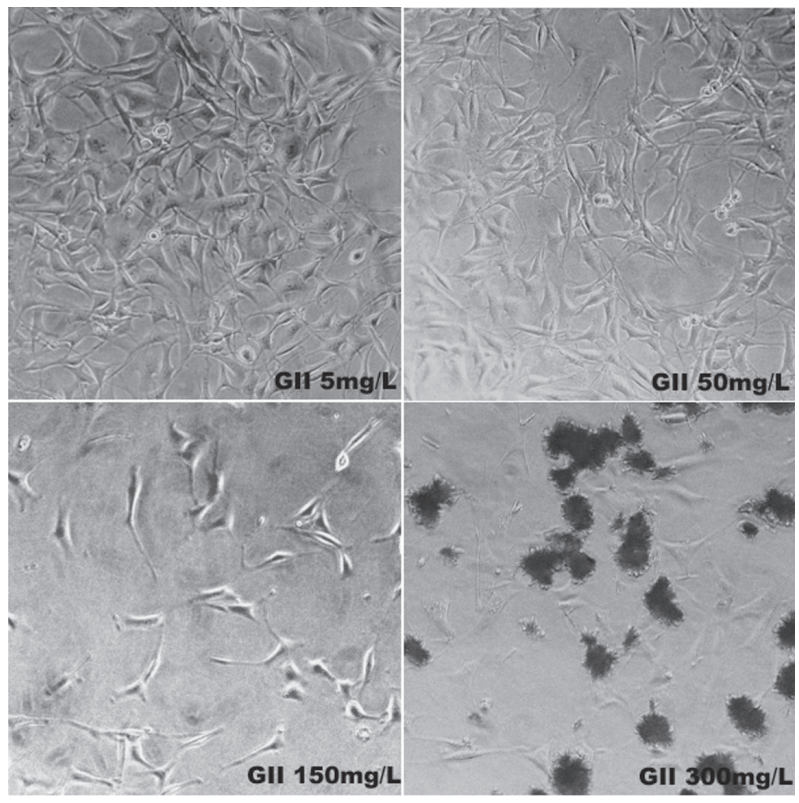

Figure 3- Photomicrographs of Group II (Ciprofloxacin) at $72 \mathrm{~h}$ 

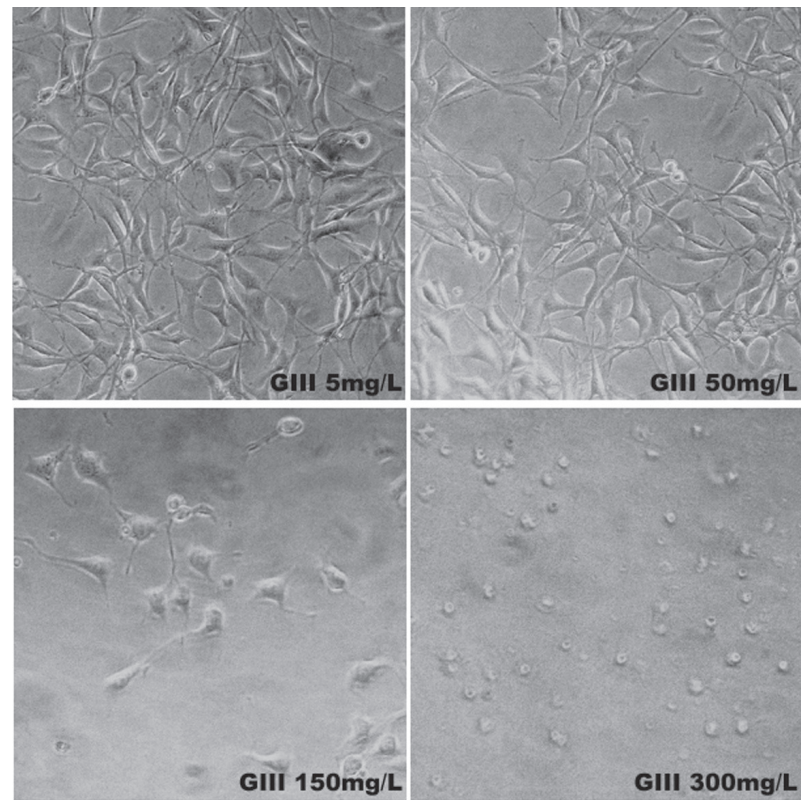

Figure 4- Photomicrographs of Group III (Clyndamicin) at $72 \mathrm{~h}$

minimal cytoplasmic extensions were observed. Treatment with $300 \mathrm{mg} / \mathrm{L}$ produced the smallest number of viable cells, which were adherent, but had no defined shape.

Figure 5 presents the metronidazole-treated group. Cells were fusiform and slightly round when compared with the control group. For the concentrations of 150 and $300 \mathrm{mg} / \mathrm{L}$, a large number of fibroblasts were seen in a disorganized arrangement, with a tendency to form clumps. Precipitated drug was observed in the bottom of the bottle.

\section{DISCUSSION}

The methodology applied in this study was based on a previous study ${ }^{6}$, which assessed biological effects of the ciprofloxacin on cell cultures. Cells selected for the assay - sixth-passage human gingival fibroblasts - were chosen due the ease of handling and metabolic potential similar to that of cells in the periapical region. It also is important to explain that the consumption of the nutrient broth by the cells is also responsible for their decreased viability. DMEM broth supplemented with $10 \%$ bovine fetal serum was chosen because it reproduces the ideal conditions for the in vitro maintenance of these cells.

The technique proposed to assess ciprofloxacin, clyndamicin and metronidazole cytotoxicity measured cell viability using the MTT assay. The efficacy of this method has been extensively demonstrated ${ }^{2,6,7,11}$. The results presented are related to the effects of three different antimicrobial compounds (ciprofloxacin, clyndamicin and metronidazole) at four different concentrations (5,
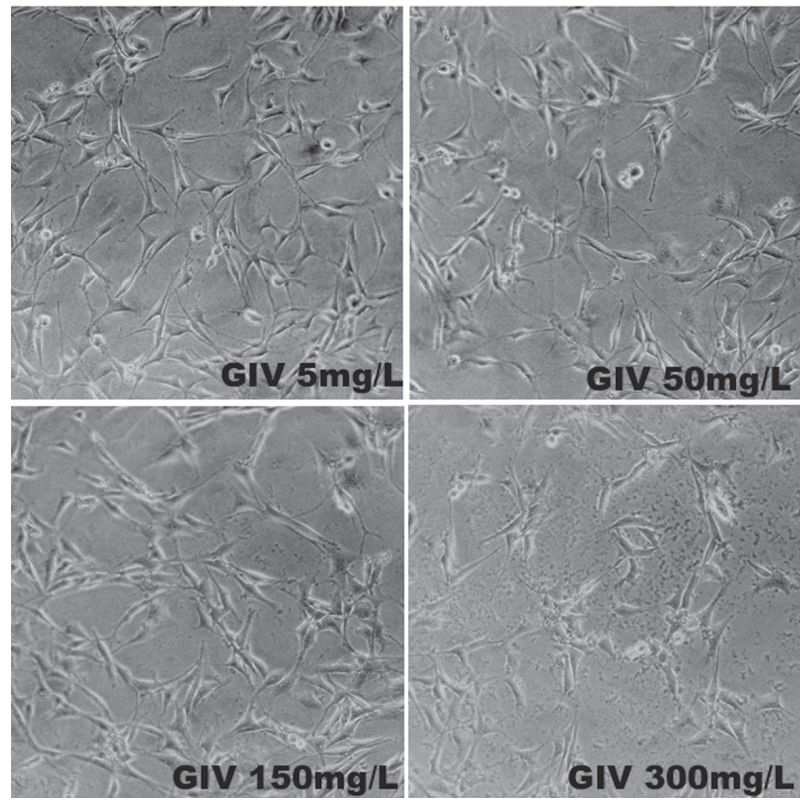

Figure 5- Photomicrographs of Group IV (Metronidazole) at $72 \mathrm{~h}$

50,150 and $300 \mathrm{mg} / \mathrm{L}$ ) at four different times (24, 48,72 and $96 \mathrm{~h}$ ) on cells in culture.

Statistical interaction of ciprofloxacin concentrations showed significant differences between the following concentrations: $5 \times 150$ $\mathrm{mg} / \mathrm{L}, 5 \times 300 \mathrm{mg} / \mathrm{L}$ and $5 \times 300 \mathrm{mg} / \mathrm{L}$ at $24 \mathrm{~h} ; 5 \times 300$ $\mathrm{mg} / \mathrm{L}$ at $48 \mathrm{~h} ; 5 \times 300 \mathrm{mg} / \mathrm{L}$ at $72 \mathrm{~h} ; 5 \times 150 \mathrm{mg} / \mathrm{L}$, $5 \times 300 \mathrm{mg} / \mathrm{L}$ and $50 \times 300 \mathrm{mg} / \mathrm{L}$ at $96 \mathrm{~h}$. According to these data and mean cell viability, the greatest concentrations produced the smallest number of viable cells compared to the control group. These results were similar to those of previous studies ${ }^{6-7}$, which showed the cytotoxicity of ciprofloxacin at concentrations above $50 \mathrm{mg} / \mathrm{L}$.

Statistical interaction of clyndamicin concentrations showed significant differences between the following concentrations: $5 \times 300 \mathrm{mg} / \mathrm{L}$, at $24 \mathrm{~h} ; 5 \times 300 \mathrm{mg} / \mathrm{L}$ at $48 \mathrm{~h} ; 5 \times 150 \mathrm{mg} / \mathrm{L}, 5 \times 300$ $\mathrm{mg} / \mathrm{L}$ and $50 \times 300 \mathrm{mg} / \mathrm{L}$ at $72 \mathrm{~h}$; and finally $5 \times 150$ $\mathrm{mg} / \mathrm{L}, 5 \times 300 \mathrm{mg} / \mathrm{L}, 50 \times 150 \mathrm{mg} / \mathrm{L}$ and $50 \times 300 \mathrm{mg} / \mathrm{L}$ at $96 \mathrm{~h}$. These results confirm those of Wijsman, et al. ${ }^{11}$ (2005) about the dose-dependent toxicity of clyndamicin.

Considering the antimicrobial action of these drugs, the findings of this study are in agreement with those of LeCorn, et al. ${ }^{9}$ (2007), who evaluated the susceptibility of several Actinomyces species to clyndamicin. Minimal inhibitory concentration of this antibiotic was $1 \mu \mathrm{g} / \mathrm{mL}$.

All concentrations of metronidazole led to at least $50 \%$ viable cells at all concentrations at all experimental times. A concentration of $5 \mathrm{mg} / \mathrm{L}$ resulted in cell viability of $73 \%$ after $96 \mathrm{~h}$.

Statistical interaction of metronidazole concentrations showed significant differences 
between the following concentrations: $5 \times 300 \mathrm{mg} / \mathrm{L}$, $50 \times 300 \mathrm{mg} / \mathrm{L}$ at $24 \mathrm{~h} ; 5 \times 150 \mathrm{mg} / \mathrm{L}$ and $5 \times 300$ $\mathrm{mg} / \mathrm{L}$ at $48 \mathrm{~h} ; 5 \times 150 \mathrm{mg} / \mathrm{L}$ and $5 \times 300 \mathrm{mg} / \mathrm{L}$ at 72 $\mathrm{h} ; 5 \times 300 \mathrm{mg} / \mathrm{L}$ at $96 \mathrm{~h}$. These results are similar to those of Carreira, et al. ${ }^{1}$ (2007) regarding the antimicrobial action of metronidazole, which found satisfactory results regarding the association with $4 \mu \mathrm{g} / \mathrm{mL}$ ciprofloxacin.

Results obtained using this methodology may serve as a motivation for new studies with the drugs used in this trial. It is important to include these findings in the critical analysis of the use of new drugs in intracanal dressing.

\section{CONCLUSION}

Based on the obtained results, the following conclusions can be drawn: 1 . All tested antibiotics (ciprofloxacin, clyndamicin and metronidazole) showed dose-dependent cytotoxicity; 2 . Regardless of the antibiotic, cell viability at $24 \mathrm{~h}$ was greater than in the other experimental times; 3 . Concentrations of 5 and $50 \mathrm{mg} / \mathrm{L}$ of all antibiotics produced viable fibroblasts at all experimental times.

\section{REFERENCES}

1- Carreira CM, Santos SS, Jorge AO, Lage-Marques JL. Antimicrobial effect of intracanal substances. J Appl Oral Sci. 2007; 15:453-8.

2- Ebisuno S, Inagaki T, Kohjimoto Y, Ohkawa T. The cytotoxic effect of fleroxacin and ciprofloxacin on transitional cell carcinoma in vitro. Cancer. 1997;80:2263-7.

3- Edwards DI. Metronidazole. In: Hahn FE. Modes and mechanisms of microbial growth inhibition. Antibiotics. New York: Spring; 1983.

4- Freshney RI. Cytotoxicity. In: Culture of animal cells: a manual of basic technique. 4th. ed. Indianapolis: Willy-Liss; 2000. p.329-44.

5- Goodson JM. Antimicrobial strategies for treatment of periodontal diseases. Periodontol 2000. 1994;64:1-12.

6- Gürbay A, Garrel C, Osman M, Richard MJ, Favier A, Hincal F. Cytotoxicity in ciprofloxacin-treated human fibroblast cells and protection by vitamin E. Hum Exp Toxicol. 2002;21:635-41.

7- Gürbay A, Gonthier B, Barret L, Favier A, Hincal F. Cytotoxic effect of ciprofloxacin in primary culture of rat astrocytes and protection by vitamin E. Toxicology. 2007;229:54-61.

8- Gürbay A, Gonthier B, Signorini-Allibe N, Barret L, Favier A, Hincal F. Ciprofloxacin-induced DNA damage in primary culture of rat astrocytes and protection by vitamin E. Neurotoxicology. 2006;27:6-10.

9- LeCorn DW, Vertucci FJ, Rojas MF, Progulske-Fox A, Bélanger M. In vitro activity of amoxicillin, clyndamicin, doxiycycline, metronidazole, and moxifloxacin against oral Actinomyces. J Endod. 2007;33:557-60.

10- Mohammadi Z. Systemic, prophylactic and local applications of antimicrobials in endodontic: an update review. Int Dent J. 2009;59(4):175-86.

11- Wijsman JA, Dekaban GA, Rieder MJ. Differential toxicity of reactive metabolites of clyndamicin and sulfonamides in HIVinfected cells: influence of HIV infection on clyndamicin toxicity in vitro. J Clin Pharmacol. 2005;45:346-51. 